\title{
Pasienter med emosjonelt ustabil personlighetsforstyrrelse trenger tilpasset akuttbehandling
}

KRONIKK

\section{ØIVIND EKEBERG}

Øivind Ekeberg er spesialrådgiver ved Klinikk psykisk helse og avhengighet, Oslo universitetssykehus, og professor emeritus ved Avdeling for medisinsk atferdsvitenskap, Institutt for medisinske basalfag, Universitetet i Oslo.

Forfatteren har fylt ut ICMJE-skjemaet og oppgir ingen interessekonflikter.

\section{ELFRIDA HARTVEIT KVARSTEIN}

Elfrida Hartveit Kvarstein er ph.d., spesialist i psykiatri, førsteamanuensis ved Institutt for klinisk medisin, Universitetet i Oslo, og seksjonsoverlege ved Seksjon for personlighetspsykiatri og spesialpoliklinikker, Klinikk psykisk helse og avhengighet, Oslo universitetssykehus. Forfatteren har fylt ut ICMJE-skjemaet og oppgir ingen interessekonflikter.

\section{$\varnothing Y$ VIND URNES}

Øyvind Urnes er spesialist i psykiatri og tidligere leder for Nasjonal kompetansetjeneste for personlighetspsykiatri ved Oslo universitetssykehus.

Forfatteren har fylt ut ICMJE-skjemaet og oppgir ingen interessekonflikter.

\section{INGEBORG ULLTVEIT-MOE EIKENAS}

Ingeborg Ulltveit-Moe Eikenæs er ph.d., spesialist i psykiatri og leder av Nasjonal kompetansetjeneste for personlighetspsykiatri ved Oslo universitetssykehus.

Forfatteren har fylt ut ICMJE-skjemaet og oppgir ingen interessekonflikter.

\section{ERLEND HEM}

E-post: erlend.hem@medisin.uio.no

Erlend Hem er fagsjef ved Klinikk psykisk helse og avhengighet, Oslo universitetssykehus, professor ved Avdeling for medisinsk atferdsvitenskap, Institutt for medisinske basalfag, Universitetet i Oslo, og redaktør for Tidsskriftets språkspalte.

Forfatteren har fylt ut ICMJE-skjemaet og oppgir ingen interessekonflikter.

Det har vært mye pessimisme knyttet til behandlingspotensialet ved emosjonelt ustabil personlighetsforstyrrelse, men det er nå økende evidens for at tilpasset behandling har god effekt. 


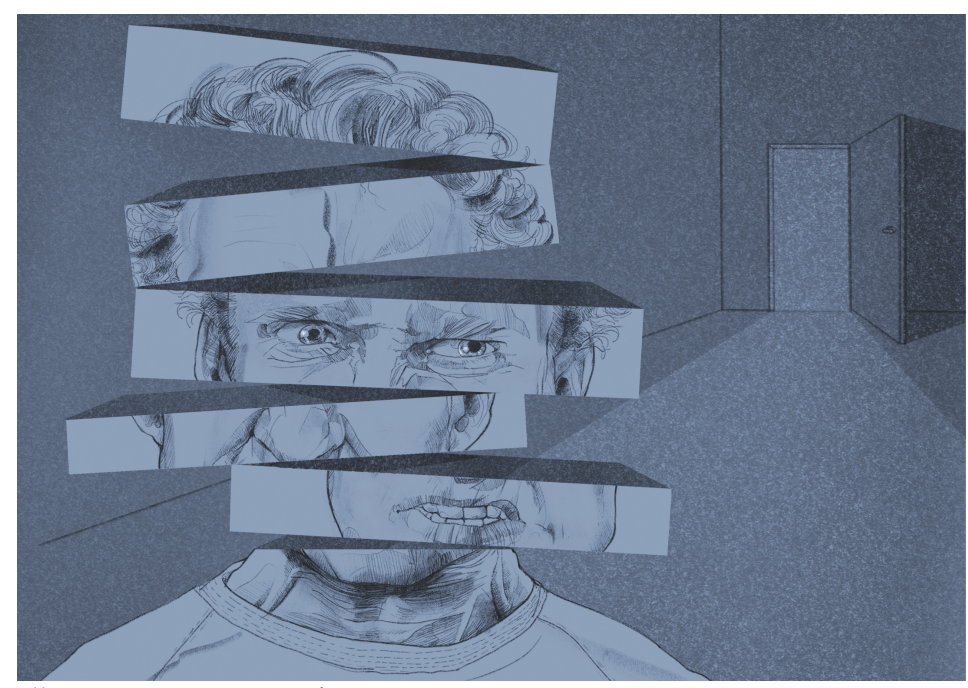

Illustrasjon: Miss Boo / Bente Jørgensen

Pasienter med emosjonelt ustabil personlighetsforstyrrelse oppfattes gjerne som utakknemlige og vanskelige å behandle. Stigma knyttet til personlighetsforstyrrelser generelt er velkjent, og det hevdes at mennesker med slike diagnoser er den mest stigmatiserte gruppen med psykisk lidelse (1).

En del pasienter som innleggende lege vurderer som akutt suicidale, blir nektet innleggelse i psykiatrisk avdeling eller skrevet raskt ut. Som omtalt i en annen artikkel i dette nummeret av Tidsskriftet mener vi at en slik praksis uttrykker en unyansert holdning og manglende individuell vurdering (2).

Erfaringer fra brukergruppen ved Nasjonal kompetansetjeneste for personlighetspsykiatri viser mange eksempler på uheldige utsagn fra behandlere i psykisk helsevern, som at «sånne som deg har ikke godt av å være i akuttavdelingen» (3). Pasientene kan bli møtt med press om tidligst mulig utskrivning før man har tatt stilling til hva som kan være til hjelp for dem. Pasienter forteller også at holdningen fra personalet forandret seg radikalt hvis diagnosen ble endret til f.eks. bipolar lidelse eller kompleks posttraumatisk stresslidelse (3). Da ble de lyttet til og fikk hjelp til krisen som de selv ikke mestret. Tilsvarende erfaringer finnes også fra somatiske avdelinger, der pasienter er blitt innlagt etter alvorlig selvmordsforsøk kort tid etter utskrivning fra psykiatrisk avdeling.

Mange som blir innlagt i somatiske avdelinger etter selvmordsforsøk, får bli en dag eller to etter at den somatiske behandlingen er avsluttet, for å få stabilisert seg psykisk før de reiser hjem. Det er ikke grunnlag for å mene at slik kortvarig ivaretagelse fremmer regresjon eller medfører mer selvmordsatferd. Det framstår derfor nærmest uforståelig for kolleger i somatikken at pasienter med et stort lidelsestrykk ikke skal kunne ivaretas i en psykiatrisk akuttavdeling i en krisesituasjon. Poenget kan illustreres med en parallell fra somatisk medisin: Pasienter med kols vil ikke nektes innleggelse i medisinsk avdeling dersom de har en forverring av lungefunksjonen med henvisning til at lungelidelsen er kronisk. Når selvmordsfaren er akutt, må det iverksettes tilstrekkelig beskyttelse.

\section{Utfordringer i akuttavdelinger}

Suicidale kriser eller selvskadende atferd er vanlig ved emosjonelt ustabil personlighetsforstyrrelse og en viktig årsak til at pasientene innlegges i akuttpsykiatriske avdelinger. Personalet er ofte engstelige for at pasienten skal gjøre alvor av planene om å ta sitt eget liv. Det kan resultere i forsøk på å kontrollere pasientens atferd og at man blir mindre oppmerksom på å hjelpe pasienten med å takle vanskelige følelser knyttet til den pågående krisen.

Det framstår nærmest uforståelig for kolleger i somatikken at pasienter med et stort lidelsestrykk ikke skal kunne ivaretas i en psykiatrisk akuttavdeling i en krisesituasjon 
Møtet med pasientene gjør noe med behandlerne. Noen kan bli idealisert, mens andre blir devaluert, og denne vekslingen kan forekomme overfor den samme behandleren. Dette kan føre til at man føler seg urettferdig behandlet, maktesløs og udugelig, eller at man tillegger pasientene at de splitter personalet i gode og onde (4). Slike motoverføringsreaksjoner finnes i alle behandlingsrelasjoner. Avvisning av pasienten er en vanlig måte å slå tilbake eller beskytte seg selv på, og man kan uttrykke dette tilsynelatende rasjonelt gjennom utsagn som: «Denne pasienten ødelegger behandlingsmiljøet og kan derfor ikke mottas på vår post» (4).

Pasientene kan være aggressive og utagerende, og tilstanden kan ytterligere kompliseres ved misbruk av rusmidler. Ikke minst kan situasjonen være tilspisset under innleggelser. Aggressiv atferd er risikofylt og krevende å håndtere, og kan lett oppfattes som "plagsomt», men det er viktig å erkjenne at slik atferd er tegn på alvorlig sviktende evne til selvregulering.

\section{Hva skal vi gjøre?}

Pasientene har ofte sterke emosjonelle reaksjoner, og selvskading kan være et forsøk på å regulere følelser (5). Deres evne til å tenke balansert og fleksibelt om mellommenneskelige hendelser er sterkt nedsatt i stressituasjoner (mentaliseringsvansker). Sårbarhet for avvisning er også et sentralt problem for mange. Selvskading og selvmordsforsøk utgjør altså kjernesymptomer ved denne tilstanden og bør derfor møtes uten fordømmelse og med en åpen holdning preget av klarhet, tydelighet og empati (4). Hjelp til å identifisere problematiske reaksjonsmønster og sårbarhet er også viktig.

I de siste årene er flere spesialiserte, polikliniske behandlingstilnærminger anbefalt. Disse psykoterapeutiske behandlingsprogrammene bør ha varighet på minst et år, ha fokus på de underliggende problemene og omfatte behandlingsplaner, kriseplaner, psykopedagogiske tiltak og strukturert, målrettet og tilpasset psykoterapi. Dialektisk atferdsterapi (dialectical behavior therapy, DBT), mentaliseringsbasert terapi (mentalization-based treatment, MBT), skjemafokusert terapi (schema-focused therapy, SFT) og STEPPS/STAIRWAY er spesialiserte tilnærminger som er etablert i Norge. Disse behandlingene har dokumentert effekt med mindre selvskading, færre innleggelser og reduksjon av generell psykopatologi (6-9).

Selvskading og selvmordsfors $\emptyset \mathrm{k} b ø \mathrm{r}$ møtes uten fordømmelse og med en åpen holdning preget av klarhet, tydelighet og empati

Man har de senere årene også hatt oppmerksomhet rettet mot å definere hvilken plass kortvarige frivillige døgninnleggelser kan ha i krisesituasjoner (10, 11). Kriseopphold kan være en del av en strukturert behandlingsplan hvor pasientene er med på planleggingsprosessen. Varigheten på oppholdet er få dager. Det finnes interessante norske initiativer til akuttpsykiatrisk behandling for denne pasientgruppen, bl.a. i Levanger og Namsos $(12,13)$. I Levanger får pasientene korte planlagte innleggelser over ett til to år, og i en ukontrollert studie reduserte dette selvskading og akuttinnleggelser (12). Opplegget i Namsos består av fire trinn og innebærer at dersom tiltakene utenfor psykiatrisk avdeling i de første tre trinnene ikke har ført fram, kan man tilby pasienten et kort kriseopphold der man sammen med pasienten lager et mål for oppholdet. Som hovedregel er oppholdet av tre dagers varighet, fortrinnsvis uten bruk av restriktive tiltak som skjerming etc., og under oppholdet vil man arbeide aktivt med å utarbeide eller tilpasse en kriseplan. Det gjøres ingen endringer av etablert poliklinisk behandlingsopplegg (13). De fleste mener at utarbeidelse av kriseplaner og planlagte kriseopphold kan redusere behovet for akuttinnleggelser selv om dokumentasjonen kan være mangelfull (14).

\section{Bedre strategier}

En nyttig strategi er å bygge opp alternative tilbud rundt pasientene, slik at behovet for akuttinnleggelser i døgnavdeling blir mindre. En trygg, forutsigbar og tilgjengelig oppfølging er viktig. 
Ofte er behandlingen som tilbys i en døgnavdeling utilfredsstillende, og mange pasienter forteller om liten nytte av innleggelsen. Det er en risiko for at pasientene bare blir «oppbevart» i avdelingen. Det er imidlertid mulig å endre på dette, bl.a. ved å gjøre det klart hvilke problemstillinger man skal arbeide med under oppholdet. En nøkkelfaktor er personalets kompetanse (15). En oversiktsartikkel over kvalitative studier viste at pasientene opplevde det positivt å bli lyttet til, få snakke med personale og medpasienter, få en pause fra dagliglivet og få følelse av trygghet og kontroll. Negative erfaringer ble tilskrevet mangel på kontakt, negative holdninger og mangel på kunnskap hos personalet, tvangsinnleggelse og dårlig forberedelse av utskrivningen (16).

Innleggelse i akuttavdeling kan brukes som en del av behandlingsopplegget, men det forutsetter at behandlere i akuttavdeling og poliklinikk er enige om hvordan pasientene skal behandles (17). Det anbefales å avtale en klar målsetting for oppholdet med pasienten inkludert hvor lenge det skal vare - og å skrive ut til veldefinert oppfølging (4). Arbeidet i avdelingen skal skje under tydelige, forutsigbare rammer, med klare grenser og med god struktur og orden (4). Personalet må få oppdatert kunnskap om emosjonelt ustabil personlighetsforstyrrelse slik at de kan møte pasientene med respekt, interesse og forståelse. Gjennom veiledning kan de læres opp til å bli klar over egne reaksjoner og ikke spille dem ut overfor pasientene.

Symptomene ved emosjonelt ustabil personlighetsforstyrrelse avtar vanligvis noe over tid. Dette gjelder særlig dramatiske trekk som selvskading og selvmordsforsøk (18). Dersom pasientene viser alvorlig selvskading eller er akutt suicidale, er det viktig å hjelpe til med å overleve krisen (4). Å motta pasienten i krisesituasjoner, men samtidig begrense oppholdenes varighet uten avvisning, blir en balansekunst.

En studie fra Sveits har vist at femdagers døgninnleggelse med et psykodynamisk program for pasienter med emosjonelt ustabil personlighetsforstyrrelse i akutt suicidal krise ga betydelig påfølgende reduksjon av reinnleggelser innen tre måneders oppfølging (19). Denne posten på et vanlig sykehus hadde åtte plasser og er et eksempel på at man kan skreddersy døgnoppholdene for denne pasientgruppen.

Oppmerksomheten bør rettes mot de mellommenneskelige omstendighetene som utløste krisen og pasientens følelser og tanker om disse. Den systematiske behandlingen av personlighetsforstyrrelsen bør være forankret poliklinisk, og akuttoppholdet bør ha som mål å hjelpe pasienten til å gjenvinne egen emosjonsregulering og evne til å tenke mer fleksibelt om seg selv og forholdet til andre (mentalisere) (5). Man må prøve å opprettholde kontakten med ansvarlig poliklinisk behandler mens pasienten er innlagt.

\section{LITTERATUR:}

1. Sheehan L, Nieweglowski K, Corrigan P. The stigma of personality disorders. Curr Psychiatry Rep 2016; 18: 11. [PubMed][CrossRef]

2. Ekeberg $\emptyset$, Kvarstein EH, Urnes $\emptyset$ et al. Suicidale pasienter med personlighetsforstyrrelse. Tidsskr Nor Legeforen 2019; 139. doi:10.4045/tidsskr.19.0493. [CrossRef]

3. Braanen JM. «Sånne som deg har ikke godt av å være innlagt». Personlighetsforstyrrelse og opplevelse av stigma i møtet med behandlingssystemet: en kvalitativ studie. Masteroppgave. Oslo: Psykologisk institutt, Universitetet i Oslo, 2018. http://urn.nb.no/URN:NBN:no-696og Lest 23.8.2019.

4. Ilner SO. Akuttpsykiatri. Oslo: Gyldendal akademisk, 2012: 120-4.

5. Bateman A, Fonagy P. Mentalization-based treatment for personality disorders: a practical guide. Oxford: Oxford University Press, 2016.

6. Linehan MM, Comtois KA, Murray AM et al. Two-year randomized controlled trial and follow-up of dialectical behavior therapy vs therapy by experts for suicidal behaviors and borderline personality disorder. Arch Gen Psychiatry 2006; 63: 757-66. [PubMed][CrossRef]

7. Bateman A, Fonagy P. Randomized controlled trial of outpatient mentalization-based treatment 
versus structured clinical management for borderline personality disorder. Am J Psychiatry 2009; 166: 1355-64. [PubMed][CrossRef]

8. Giesen-Bloo J, van Dyck R, Spinhoven P et al. Outpatient psychotherapy for borderline personality disorder: randomized trial of schema-focused therapy vs transference-focused psychotherapy. Arch Gen Psychiatry 2006; 63: 649-58. [PubMed][CrossRef]

9. Stoffers JM, Völlm BA, Rücker G et al. Psychological therapies for people with borderline personality disorder. Cochrane Database Syst Rev 2012; 8: CDoo5652. [PubMed]

10. Castillo H, Ramon S, Morant N. A recovery journey for people with personality disorder. Int J Soc Psychiatry 2013; 59: 264-73. [PubMed][CrossRef]

11. Mortimer-Jones S, Morrison P, Munib A et al. Recovery and borderline personality disorder: a description of the innovative open borders program. Issues Ment Health Nurs 2016; 37: 624-30. [PubMed][CrossRef]

12. Torgersen T, Løvås E, Tofte T. Korte, planlagte innleggelser ved villet egenskade. Tidsskr Nor Lægeforen 2007; 127: 1521-3. [PubMed]

13. Selvik SG, Torvin GS, Haug I et al. Pasienter i krise. Tidsskr Nor Legeforen 2014; 134: 1640-1. [PubMed][CrossRef]

14. Borschmann R, Henderson C, Hogg J et al. Crisis interventions for people with borderline personality disorder. Cochrane Database Syst Rev 2012; 6: CDoo9353. [PubMed][CrossRef]

15. Bodner E, Cohen-Fridel S, Mashiah M et al. The attitudes of psychiatric hospital staff toward hospitalization and treatment of patients with borderline personality disorder. BMC Psychiatry 2015; 15: 2. [PubMed][CrossRef]

16. Stapleton A, Wright N. The experiences of people with borderline personality disorder admitted to acute psychiatric inpatient wards: a meta-synthesis. J Ment Health 2019; 28: 443-57.

[PubMed][CrossRef]

17. Hong V. Borderline personality disorder in the emergency department: Good Psychiatric Management. Harv Rev Psychiatry 2016; 24:357-66. [PubMed][CrossRef]

18. Zanarini MC, Frankenburg FR, Reich DB et al. Time to attainment of recovery from borderline personality disorder and stability of recovery: A 10-year prospective follow-up study. Am J Psychiatry 2010; 167: 663-7. [PubMed][CrossRef]

19. Berrino A, Ohlendorf P, Duriaux S et al. Crisis intervention at the general hospital: an appropriate treatment choice for acutely suicidal borderline patients. Psychiatry Res 2011; 186: 287-92.

[PubMed][CrossRef]

Publisert: 21. oktober 2019. Tidsskr Nor Legeforen. DOI: 10.4045/tidsskr.19.0492

Mottatt 1.8.2019, godkjent 23.8.2019.

(C) Tidsskrift for Den norske legeforening 2020. Lastet ned fra tidsskriftet.no 